\title{
Identify Maths Learning Difficulties on the Set Subject
}

\author{
Ahmad Faris Alfiyansah*, Annisa Fitriani, Hega Narimoati, Meli Handayani \\ Mathematics Education Department, Faculty of Teacher Training and Education, Tidar University \\ J1. Kapten Suparman No 39, Tuguran, Potrobangsan, Kec. Magelang Utara, Kota Magelang, Jawa Tengah 56116, Indonesia. \\ Tel. (0293) 364113, Fax. (0293) 362438. \\ Email*: farisalfiyansah06@gmail.com
}

\begin{abstract}
Abstact. In conducting students' learning activities that do not always work, there are often things that cause failure. The study aims to describe the difficulties students have experienced and to study the mistakes of the students in working on the tests in mathematics learning on the set subject. This type of research is a qualitative descriptive with a case study approach. Data collection techniques with problem instruments, interviews, and documentation. The legitimacy of data using technique triangulation. Data analysis through the data reduction phase, data presentation, and withdrawal of conclusions. The research was conducted with the subject of his research 30 students. The results showed that the type of difficulties experienced by students in the form of 1) difficulty in understanding the problem is the inability of the students to interpret the mathematical symbols on the subject of the set, 2) difficulty transforming that is the inability of students determining the set formula, 3) difficulty in the completion process is that students are not able to perform binary counting operations to solve the set problem. Then it can be concluded the types of difficulty learning mathematics that students experience in the subject of the association can be classified into 3 types, namely difficulty in understanding the problem, difficulty transforming the problem, and difficulty solving problems.
\end{abstract}

Keywords: mathematics learning difficulties, set, the kind of difficulty.

\section{INTRODUCTION}

Piaget (1972) in Reys, et all (2012:19) states that mathematics is made (constructed) by children, not found like a rock norreceived from others as gift. Mathematics is made by students themselves, not found like rocks or a gift. The purpose of learning mathematics is to build student knowledge about the concept of mathematics (Herani Tri Lestiana, Sri Rejeki, Fariz Setyawan: 2016). The purpose of mathematics is that the students have the ability to solve problems that include the ability to understand problems, design mathematical models, complete models and interpret acquired solutions and tenacious attitudes and believe In solving the problem according to Mustika (in Sinta Ratnasari, Wahyu Setiawan,2019). Learning good mathematics according to Rusfendi (in Fakhrul Jamal: 2014) is that the students understand the concept of mathematics, preferably taught in the order of basic concepts, then with the concept of applied, in addition to be adapted to learner level.

In conducting students' learning activities does not always work, there are often things that cause failure. The causes of failures include threats from the surrounding environment, the difficulties of learning the students, and the barriers from inside or outside students. Learning difficulties in mathematical subjects has its own distinctive style and characteristics when compared to learning difficulties in other subjects. According to Wood (in Sinta Ratnasari, Wahyu Setiawan,2019) that some characteristics of students' difficulties in mathematics learning are: (1) difficulty differentiating numbers, symbols, and building space, (2) not able to remember the evidence of mathematics, (3) write the numbers unreadable or in small size, (4) do not understand the mathematical symbols, (5) weakness of the ability of abstract thinking, (6) weak ability of metacognition (weak ability to identify and utilize algorithms in solving math problems). This learning difficulty occurs because students experience obstacles and distractions. For example, it cannot associate a new lesson with a long lesson.

Similarly, the mathematical subjects, the symptoms of learning difficulties will be seen when students are unable to master the material, so that the students obtain less fulfilling learning outcomes. According to Syaiful Bahri Djamarah (2003:201) difficulty in learning is a condition where the students can not learn reasonably, because of threats, obstacles or disturbance in learning. The difficulties experienced by students resulted in the learning process being obstructed, not infrequently students have to repeat only because of difficulty studying academically. Based on research conducted by Lina Maftukhah (2012) the factors of the cause of student learning difficulties are the students' ability factor, the teacher's ability factor, supporting means factor, school support factor, and the family support factor.

Based on the above background, the researcher will conduct a preliminary study titled "Identifying the difficulties of mathematical learning in the subject matter". Researchers view important materials as the set- 
form material is an essential material. Based on the explanation, there are problems, namely any kind of difficulties experienced by the students of Magelang class in learning Mathematics on the subject of the set?

Based on the exposure that has been presented above, the research conducted aims to inform the difficulties experienced by the students on the subject of the association. From that information, it is very important for teachers to perform assessments in order to know the extent to which students understand a given topic and the difficulty and what causes mistakes and solutions to avoid the same mistakes future. With this research, it is hoped that there will be new learning alternatives that can be used to improve students ' understanding of the set's subject concept. So learning will be more meaningful and understandable to students.

\section{MATERIALS AND METHODS}

The type used in this study is qualitative descriptive research. Qualitative research was chosen to know deeper and detailed issues to be examined. The subject in this study was 30 students in MAN Magelang, which was selected purposive sampling. The collection of data in this study uses the instruments of questions, interviews, and documentation. The shell of the test material is the set material. This research uses the instrument (test) in the form of a description (essay) amounted to 8 questions. The scope of the material used is the set material.

\section{RESULTS AND DISCUSSION}

Based on the results of the interviews and the test of the given problem, obtained data about the difficulties experienced by the students in learning mathematics on the subject of the association. The types of math learning difficulties that students experience in the subject matter of the association can be classified into 3 types, namely, difficulty understanding the problem, difficulty transforming the problem, and difficulty solving the problem. Here's the description of the difficulties.

\section{Trouble Understanding the problem}

Difficulty in understanding the problem is difficulties in the form of students are able to read the problem but do not understand or understand the overall meaning of the words in the problem so that students can not move further throughout the problem-solving flow. Because students cannot write down what is known and what is asked of the question. The location of the difficulties experienced by students can be seen in the students' answers on numbers 5, 6 and 8 .

Here are the questions and answers of students at number 5:

\section{5. $A=\{x \mid 1<x<5$, maka $x$ ialah bilangan bulat $\}$. \\ $B=\{x \mid x \leq 5$, maka $x$ ialah bilangan prima $\}$. \\ Maka tentukanlah hasil dari A U B?}

Figure 1. Question number 5.

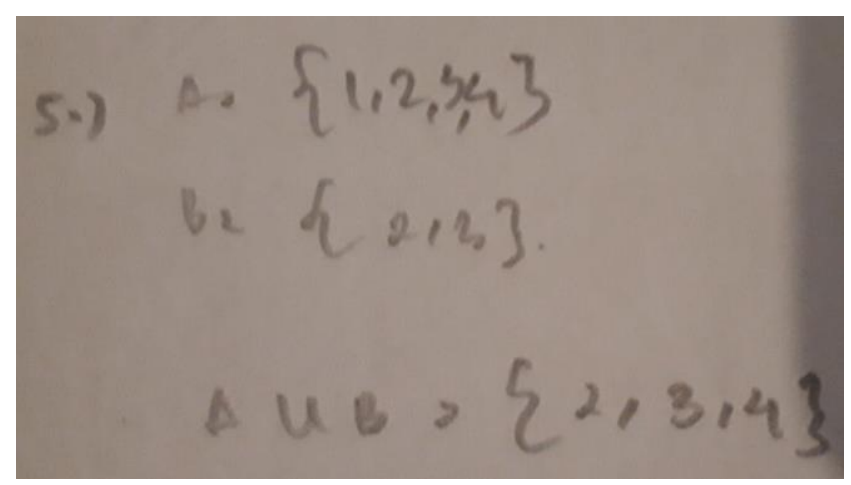

Figure 2. Student answers to question number 5.

In Question No. 5 of students' work appears that students have difficulty understanding the problem, i.e. students cannot understand what is known and what is asked. It should be from the question that students can understand what is known as Integer $\mathrm{X}$ more than 1 and less than 5 is $\{2,3,4\}$, Y prime number less than equal to 5 is $\{2,3,5\}$. Then new students can step into the next step and complete the question. The results of interviews with students indicate that the students' difficulties are in the moment that students understand the mathematical words and symbols in question.

The difficulty of understanding this problem is due to the of the students to the mathematical symbols in the matter so that students struggle to interpret the mathematical symbols and can not find the keywords of the question. It is in line with the research result of Murdanu (2004) which says that students' difficulties include: difficulty interpreting the information in question, language difficulties, difficulty understanding concepts and principles in geometry and technical difficulties. Students who are unable to write down what is learned and asked questions of the problem will have difficulty in determining the next step or subsequent procedure so that the problem given is not resolved properly. This is because translating the problem is the basic ability to understand the problem for the first step in solving the problem.

\section{Trouble transforming the problem}

Difficulty in transforming the problem is the difficulties of students in determining the formula that should be used to solve the problem. The student's difficulty lies in the question of numbers $1,2,3,4$ and 7 .

Here are the questions and answers of students at number 4 
4. Siswa kelas 7 SMP Maju Jaya adalah 45. tiap-tiap siswa memilih dua jenis pelajaran yang mereka sukai. diketahui ada 27 siswa yang menyukai pelajaran Matematika dan 26 siswa menyukai pelajaran Bahasa Inggris. Sementara siswa yang tidak menyukai kedua pelajaran tersebut ada 5 orang. Tentukanlah banyaknya siswa yang menyukai pelajaran bahasa inggris dan matematika serta buat diagram venn-nya.

Figure 3. Question number 4.

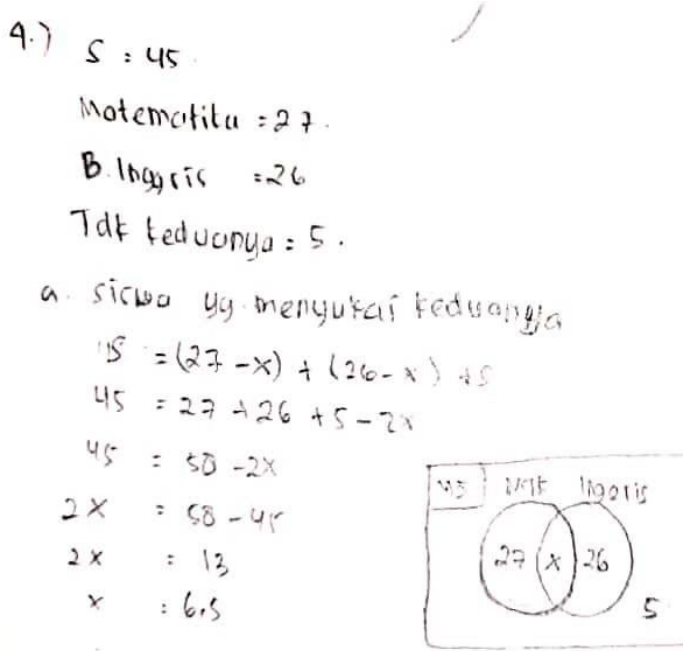

Figure 4. Student answers to question number 4.

From the interviews above, it can be noted that students can understand what is known and what to ask. But students have not been able to write the formula appropriately because of learning students who only memorize the formula so that students quickly forget the formula and the material delivered. So that students are unable to transform i.e. students forget the completion formula for the number of students who like both lessons. The student should be able to finish with the formula $\mathrm{N}\{\}=(\mathrm{n}\{\mathrm{A}\}+\mathrm{N}\{\mathrm{B}\})-(\mathrm{N}\{\mathrm{S}\}-\mathrm{n}\{\mathrm{X}\})$. Once the value of $\mathrm{N}\{\}$ is further closed to students who like English lessons and students who enjoy math lessons, so many students who love English language lessons and or mathematics are answered.

It is in line with research conducted by Retno Dewi Tanjungsari (2012) who concluded that: (1) difficulty in translating (linguistic knowledge) is addressed by mistake in interpreting language: (2) difficulties in using the principle, demonstrated students are not able to understand the variables, lack of mastery of algebraic and lack of understanding ability (schematic knowledge) shown with errors in altering the form of equations, errors in computing Algebra, difficulty in applying the principle and error of operating numbers: (3) difficulty in using the concept aimed at the inability to remember the concept, the inability to DECT concept information and lack of understanding ability (schematic knowledge) is demonstrated with a less complete writing formula: (4) difficulties in algorithm capabilities include lack of planning (strategy knowledge) and in the ability to resolve (algorithmic) demonstrated by not working problem, not finished, lack of thoroughness to do. In this case, the researcher is in line with the result of Retno Dewi Tanjungsari, and the team on the third point.
Students who are unable to recall concepts, degrade concept information and do not understand the concept are students who are unable to write a complete formula or cannot write down what procedures should be chosen. In addition, the difficulty in this model is if the student is able to degrade the concept and can write the formula or procedure well but can not use it properly to solve the problem.

\section{Difficulty in completing the problem}

The difficulty in solving the problem is the difficulty in performing a calculated and less thorough operation when the process finds an answer. The student's difficulty lies in the question of numbers $2,4,5$, and 6 .

Here are the questions and answers of students at number 2:

\section{Di dalam sebuah ruangan terdapat 150 siswa yang baru lulus SMP. Diketahui ada 75 siswa memilih untuk masuk SMA dan 63 siswa memilih untuk masuk SMK sementara ada 32 siswa yang belum menentukan pilihannya. Lalu, berapakah banyaknya siswa yang hanya memilih untuk masuk SMA dan SMK saja?}

Figure 5. Question number 2.

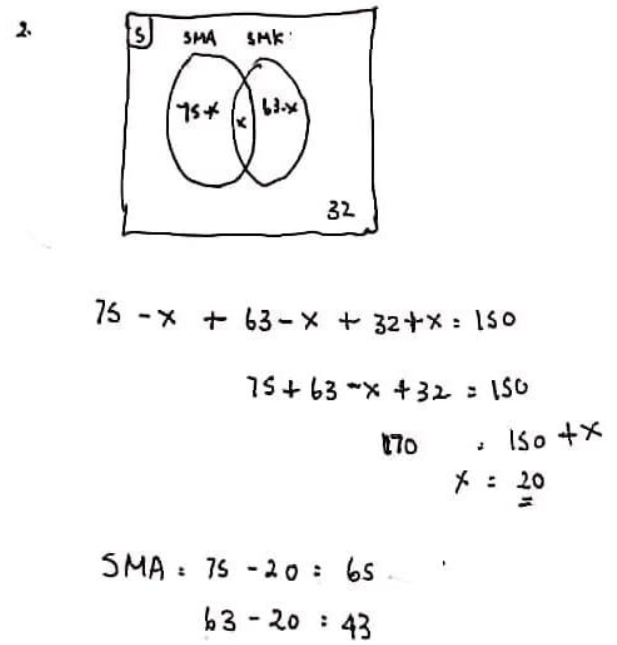

Figure 6. Student answers to question number 2.

The process of the work is correct, but when the students are faced with a counting operation that moved the segments of the students still experiencing difficulties, this causes the students not able to solve the problem correctly. The initial step of the student in converting the story to the Venn diagram and from the Venn diagram to the mathematical sentence form is correct and the student is able to perform the addition operation and reduction of algebraic form in the same section. But when looking for the $\mathrm{X}$ value, students have difficulty because they are not able to perform the counting operations in two sections. In line with research conducted by Lawrance Mundia (2012) some students' difficulties include the inability to use four arithmetic operations efficiently. Students who are in the category of difficulties in solving the problem are the students 
who make mistakes in the calculation process in solving steps. In this case, the students are not careful or thorough in doing such calculations in reducing and not able to operate the addition and reduction of the two segments.

\section{CONCLUSION}

Based on the results of data analysis and the discussion that has been outlined in the previous chapter, it can be concluded, the types of math learning difficulties experienced by students in the set chapter can be classified into 3 types, namely: 1) difficulty in understanding the problem, that is, the difficulties that the students are able to read about but do not understand or understand the overall meaning of the words in the problem, so that students are not able to go further along the problem solving, 2) difficulty in transforming the problem, which is the difficulty of the students in determining the formula that should be used to solve the problem, 3) difficulties in solving the problem, namely the difficulty in performing a calculated and less thorough operation during the process of finding an answer.

\section{ACKNOWLEDGEMENT}

Praise to Allah SWT, for the overflow of His grace and grace, so that the author can finish the research with the title: identify Maths Learning Difficulties on the Set Subject. We would like to thank our reviewers of this paper for their insightful advice and Journal Editor for their attention to detail. We also thank Fadhillah Rahmawati, S. Pd., M. Pd., (Tidar of University) for his commentary on the initial draft of this paper.

\section{REFERENCES}

Dewi, Retno Tanjungsari, dkk. 2012. Diagnosis Kesulitan Belajar Matematika SMP Pada Materi Persamaan Garis Lurus. Unnes Journal of Mathematics.

Djamarah, Syaiful Bahri. 2003. Psikologi Belajar. Jakarta: Rineka Cipta.

Jamal, Fakhrul. 2014. Analisis Kesulitan Belajar Siswa Dalam Mata Pelajaran Matemtaika Pada Materi Peluang Kelas XI IPA SMA Muhammadiyah Meulaboh Johan Pahlawan. Jurnal MAJU (Jurnal Pendidikan Matematika) Vol.1No.1:18-36

Lestiana., Herani Tri, Sri Rejeki, Fariz Setyawan. 2016.Identifying Students' Error'S on Fractions: Journal of Research and Advancesin Mathematics Education Vol. 1, No. 2, 131 - 139.

Maftukhah, Lina. 2012. Faktor-Faktor Yang Mempengaruhi Kesulitan Belajar IPS Terpadu Kelas VII di Smp Negeri 1 Platungan Kaupaten Kendal. Jurnal EEAJ (Economic Education Analysis Journal).

Mundia, Lawrence. 2012. The Assesssment of Math Learning Difficulties In a Primary Grade-4 Child with High Support Needs: Mixed Methods Approach. International Electronic Journal of Elementary Education Vol.4 (2) hal. 347-366

Murdanu. 2004. Analisis Kesulitan Siswa - Siswa SLTP dalam Menyelesaikan Persoalan Geometri. Surabaya: Universitas Negeri Surabaya.

Ratnasari., Sinta, Wahyu Setiawan. 2019. Analisis kesulitan belajar siswa pada materi himpunan.Jawa Barat : IKIP Siliwangi.

Reys, Robert. et all. 2012. Helping Children Learn Mathematics $10^{\text {th }}$ Edition. John iley \& sons: USA 